\section{Thoracoabdominal impalement with criminal intent}

\section{Dear Editor,}

A 58-year-old male was the victim of physical aggression with impalement by a broomstick. He presented mental confusion, poor response to verbal requests, tachypnea, sweating, and chest pain. Physical examination demonstrated anal bleeding. Thoracoabdominal computed tomography (CT) showed a well-delineated, cylindrical, hypodense $(-501 \mathrm{HU})$ structure extending from the pelvis to the left hemithorax, with pulmonary laceration accompanied by hydropneumothorax (Figure 1). The foreign body measured $40 \mathrm{~cm}$ in length and $2.5 \mathrm{~cm}$ in width. Emergency midline laparotomy and left thoracotomy revealed the foreign body (a broomstick), extraperitoneal perforation of the rectum, and laceration of the left hemidiaphragm with hemopneumothorax. No significant vascular injury was observed. Colostomy, suture of the diaphragmatic injury, and thoracic drainage were performed. The patient was discharged in good condition after 15 days.

Acute abdominal diseases have been the subject of several recent publications in the radiology literature of Brazil ${ }^{(1-6)}$. Many transanal impalement injuries result from the insertion of foreign bodies (solid elongated objects) into the rectum. Transanal injuries include iatrogenic cases and those related to sexual activities and violent actions. They often involve damage to multiple organs, depending mostly on the direction and nature of the penetrating object ${ }^{(7-9)}$. Impalement injuries are often as- sociated with vascular and visceral damage, entailing significant morbidity and mortality. However, some cases involve no major injuries, potentially because the rounded ends of foreign objects act as blunt tunnelers, resulting in displacement, rather than penetration, of the major visceral and vascular structures ${ }^{(8-11)}$. The clinical diagnosis of these injuries can be challenging. In the case reported here, the patient presented mental confusion and the impaling object was not visible on physical examination. The use of CT allowed us to establish the diagnosis and to predict the extent of the various injuries preoperatively.

In conclusion, combined thoracic and abdominal trauma after rectal impalement is a serious medical situation that calls for the involvement of a multidisciplinary surgical team, with the participation of a thoracic surgeon and an abdominal surgeon. CT is a useful tool for the assessment of retained wooden foreign bodies and for the evaluation of the extent of the injuries.

\section{REFERENCES}

1. Miranda CLVM, Sousa CSM, Cordão NGNP, et al. Intestinal perforation: an unusual complication of barium enema. Radiol Bras. 2017;50: 339-40.

2. Frota Júnior JH, Pereira MAH, Lopes PGM, et al. Intestinal strongyloidiasis: radiological findings that support the diagnosis. Radiol Bras. 2017;50:137-8

3. Pessôa FMC, Bittencourt LK, Melo ASA. Ogilvie syndrome after use of vincristine: tomographic findings. Radiol Bras. 2017;50:273-4.

4. Niemeyer B, Correia RS, Salata TM, et al. Subcapsular splenic hematoma and spontaneous hemoperitoneum in a cocaine user. Radiol Bras. 2017;50:136-7.

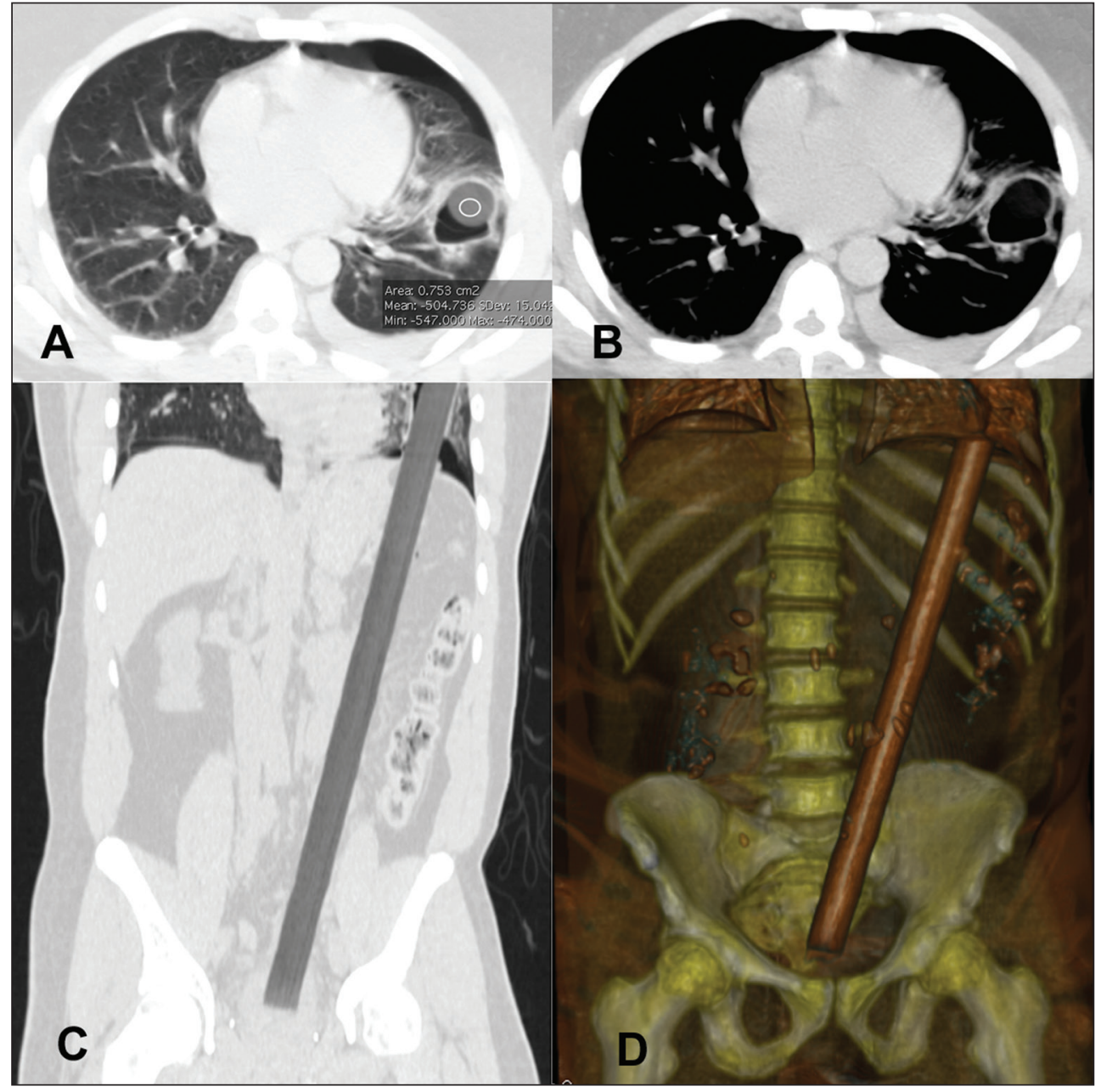

Figure 1. Axial CT with mediastinal and lung window settings (A and $\mathbf{B}$, respectively) showing a laceration on the left lower lobe, accompanied by hydropneumothorax. Note also a hypodense (-501 HU) rounded structure within the cavity (in $\mathbf{B}$ ). Coronal reconstruction $(\mathbf{C})$ and volumerendered frontal view (D) demonstrating the extent of the impalement, showing the proximal end of the broomstick in the pelvis and the distal end in the left hemithorax. 
5. Sala MAS, Ligabô ANSG, Arruda MCC, et al. Intestinal malrotation associated with duodenal obstruction secondary to Ladd's bands. Radiol Bras. 2016;49:271-2.

6. Nicolodi GC, Trippia CR, Caboclo MFFS, et al. Intestinal perforation by an ingested foreign body. Radiol Bras. 2016;49:295-9.

7. Gómez Hernández MT, Rodríguez Pérez M, Jiménez MF. Thoracoabdominal impalement by a tree branch. Arch Bronconeumol. 2015;51:468-9.

8. Kasapas K, Daskalaki A, Kaimasidis G, et al. Successful management of a combined abdominal and thoracic trauma with rectal impalement: report of a case. Case Rep Surg. 2013;2013:816089.

9. Ho LC, El Shafei H, Barr J, et al. Rectal impalement injury through the pelvis, abdomen and thorax. Ann R Coll Surg Engl. 2012;94:e201-3.
10. Moncure M, Konie JA, Kretzer AB, et al. Survival following rectal impalement through the pelvic, abdominal, and thoracic cavities: a case report. Case Rep Med. 2009;2009:361829.

11. Lupascu C, Fotea V, Sârbu P, et al. Rectal impalement injury: from cruelty to salvage endeavour. Chirurgia (Bucur). 2015;110:60-5.

Antonio Gabriel de Jesus Barbosa ${ }^{1}$, Gláucia Zanetti ${ }^{1}$, Edson Marchiori ${ }^{1}$ 1. Universidade Federal do Rio de Janeiro (UFRJ), Rio de Janeiro, RJ, Brazil. Mailing address: Dr. Edson Marchiori. Rua Thomaz Cameron, 438, Valparaíso. Petrópolis, RJ, Brazil, 25685-120. E-mail: edmarchiori@gmail.com.

http://dx.doi.org/10.1590/0100-3984.2016.0205
Subinvolução do leito placentário associada a área focal de produtos retidos da concepção e acretismo superficial mimetizando malformação arteriovenosa uterina na TC e na RM: uma lição a ser aprendida

Subinvolution of the placental site associated with focal retained products of conception and placenta accreta mimicking uterine arteriovenous malformation on CT and MRI: a lesson to be learned

\section{Sr. Editor,}

Paciente do sexo feminino, 36 anos, G5A4P1 (parto cesariano de gemelar), com antecedentes de síndrome do anticorpo antifosfolipídio, doença hipertensiva específica da gestação e procedimentos com vídeo-histeroscopia. A partir do $12^{\circ}$ dia pósparto iniciou-se sangramento vaginal volumoso, e com base na hipótese diagnóstica de produtos retidos da concepção (PRCs) valores séricos de b-HCG próximos a zero -, optou-se por seguimento clínico com avaliações ultrassonográficas seriadas, que invariavelmente indicavam a presença de uma formação ecogênica grosseiramente nodular, medindo até $2,2 \mathrm{~cm}$, situada junto ao endométrio fúndico, com sinal vascular interno ao Doppler colorido (Figura 1A). Em razão da não resolução do quadro após cerca de 60 dias, optou-se por realização de curetagem. Durante o procedimento a paciente evoluiu com volumoso sangramento (500 mL) e hipotensão, não se identificando PRCs. Tomografia computadorizada (Figura 1B) e ressonância magnética (Figuras $1 \mathrm{C}$ e 1D) da pelve, subsequentemente, confirmaram a presença da formação nodular junto ao endométrio fúndico, com intenso realce ao meio de contraste e se comunicando a uma rede de vasos miometriais dilatados e tortuosos. Em correlação com os dados clínicos (sangramento de difícil resolução, piora expressiva durante manipulação cirúrgica, ausência de PRCs à curetagem), tais achados de imagem permitiram considerar a possibilidade de má-formação arteriovenosa (MAV) adquirida ${ }^{(1)}$. Devido à falha de resposta ao tratamento conservador, optou-se por realização de histerectomia. O diagnóstico anatomopatológico foi de PRCs em uma área focal de acretismo superficial cursando com subinvolução do leito placentário (SILP).
Figura 1. A: Ultrassonografia transvaginal mostrando eco endometrial heterogêneo, com fluxo ao Doppler colorido, sobretudo em formação grosseiramente nodular na região fúndica (seta). B: Tomografia computadorizada com contraste e reconstrução MIP identificando vasos miometriais e periuterinos proeminentes em comunicação com a área nodular hipervascularizada (seta). C,D: Ressonância magnética (sagital T2 e axial T1 pós-contraste, respectivamente) confirmando os achados de dilatação vascular caracterizada pelo flow void na parede posterior uterina (seta em C) e de intensa vascularização do nódulo fúndico (seta em D).

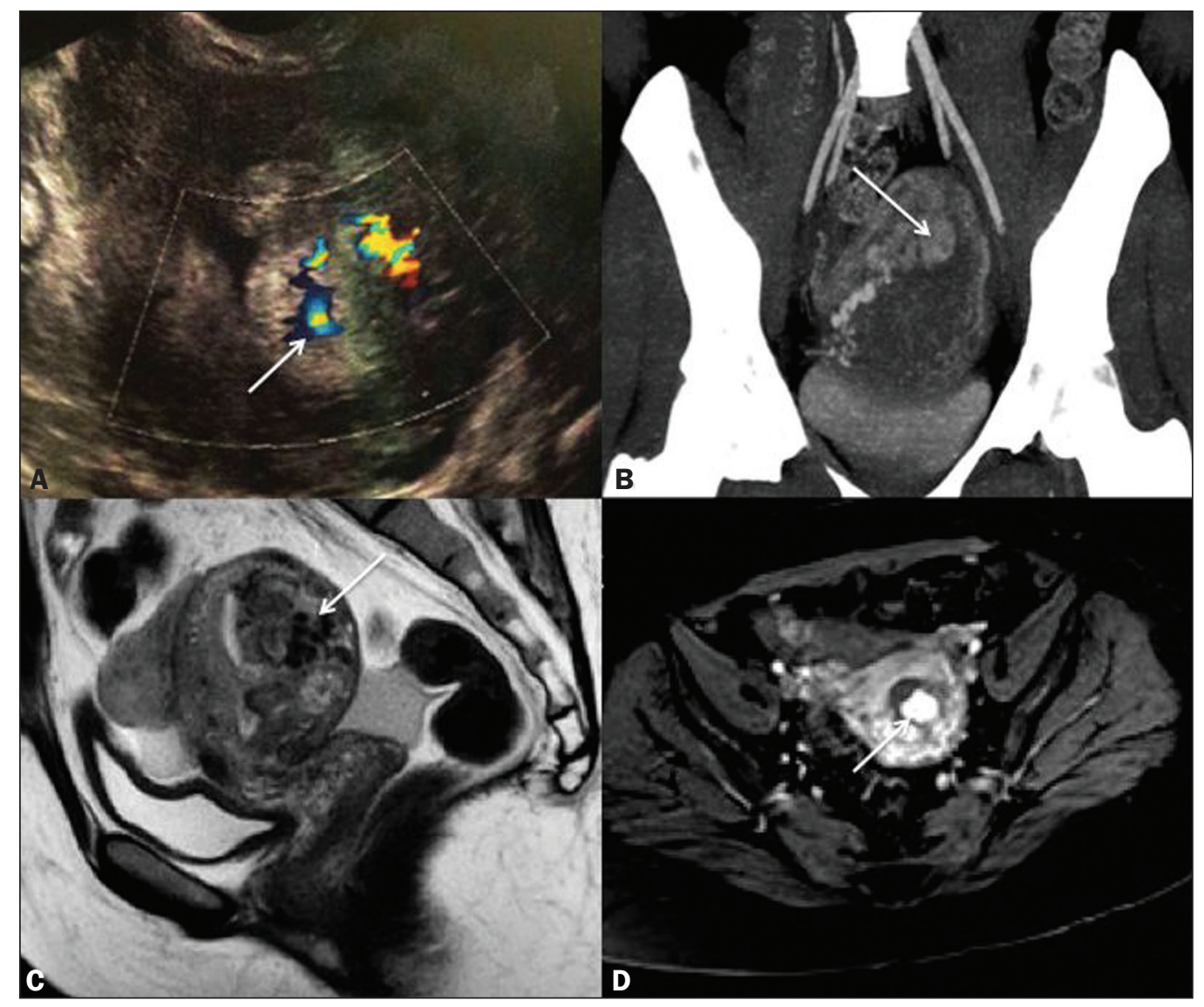

